\title{
Postgraduate ethics training programs: a systematic scoping review
}

Daniel Zhihao Hong ${ }^{1,2}$, Jia Ling Goh'1,2, Zhi Yang Ong ${ }^{1,2}$, Jacquelin Jia Qi Ting ${ }^{1,2}$, Mun Kit Wong ${ }^{1,2}$, Jiaxuan Wu $\mathbf{W}^{1,2}$, Xiu Hui Tan ${ }^{1,2}$, Rachelle Qi En Toh ${ }^{1,2}$, Christine Li Ling Chiang ${ }^{1,2}$, Caleb Wei Hao Ng ${ }^{1,2}$, Jared Chuan Kai Ng ${ }^{1,2}$, Yun Ting Ong ${ }^{1,2}$, Clarissa Wei Shuen Cheong ${ }^{1,2}$, Kuang Teck Tay ${ }^{1,2}$, Laura Hui Shuen Tan ${ }^{1,2}$, Gillian Li Gek Phua ${ }^{2,3}$, Warren Fong 1,3,4, Limin Wijaya ${ }^{3,5}$, Shirlyn Hui Shan Neo ${ }^{2}$, Alexia Sze Inn Lee ${ }^{6}$, Min Chiam6,

Annelissa Mien Chew Chin ${ }^{7}$ and Lalit Kumar Radha Krishna ${ }^{1,2,6,8,9,10^{*}}$

\begin{abstract}
Background: Molding competent clinicians capable of applying ethics principles in their practice is a challenging task, compounded by wide variations in the teaching and assessment of ethics in the postgraduate setting. Despite these differences, ethics training programs should recognise that the transition from medical students to healthcare professionals entails a longitudinal process where ethics knowledge, skills and identity continue to build and deepen over time with clinical exposure.

A systematic scoping review is proposed to analyse current postgraduate medical ethics training and assessment programs in peer-reviewed literature to guide the development of a local physician training curriculum.

Methods: With a constructivist perspective and relativist lens, this systematic scoping review on postgraduate medical ethics training and assessment will adopt the Systematic Evidence Based Approach (SEBA) to create a transparent and reproducible review.
\end{abstract}

Results: The first search involving the teaching of ethics yielded 7669 abstracts with 573 full text articles evaluated and 66 articles included. The second search involving the assessment of ethics identified 9919 abstracts with 333 full text articles reviewed and 29 articles included. The themes identified from the two searches were the goals and objectives, content, pedagogy, enabling and limiting factors of teaching ethics and assessment modalities used. Despite inherent disparities in ethics training programs, they provide a platform for learners to apply knowledge, translating it to skill and eventually becoming part of the identity of the learner. Illustrating the longitudinal nature of ethics training, the spiral curriculum seamlessly integrates and fortifies prevailing ethical knowledge acquired in medical school with the layering of new specialty, clinical and research specific content in professional practice. Various assessment methods are employed with special mention of portfolios as a longitudinal assessment modality that showcase the impact of ethics training on the development of professional identity formation (PIF).

(Continued on next page)

\footnotetext{
* Correspondence: Ialit.radha-krishna@liverpool.ac.uk

'Yong Loo Lin School of Medicine, National University of Singapore, NUHS

Tower Block, 1E Kent Ridge Road, Level 11, Singapore 119228, Singapore

${ }^{2}$ Division of Supportive and Palliative Care, National Cancer Centre Singapore,

11 Hospital Cr, Singapore 169610, Singapore

Full list of author information is available at the end of the article
}

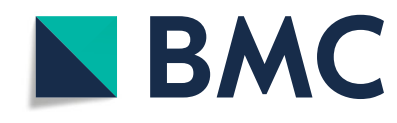

(c) The Author(s). 2021 Open Access This article is licensed under a Creative Commons Attribution 4.0 International License which permits use, sharing, adaptation, distribution and reproduction in any medium or format, as long as you give appropriate credit to the original author(s) and the source, provide a link to the Creative Commons licence, and indicate if changes were made. The images or other third party material in this article are included in the article's Creative Commons licence, unless indicated otherwise in a credit line to the material. If material is not included in the article's Creative Commons licence and your intended use is not permitted by statutory regulation or exceeds the permitted use, you will need to obtain permission directly from the copyright holder. To view a copy of this licence, visit http://creativecommons.org/licenses/by/4.0/. The Creative Commons Public Domain Dedication waiver (http://creativecommons.org/publicdomain/zero/1.0/) applies to the data made available in this article, unless otherwise stated in a credit line to the data. 
(Continued from previous page)

Conclusions: Our systematic scoping review has elicited key learning points in the teaching and assessment of ethics in the postgraduate setting. However, more research needs to be done on establishing Entrustable Professional Activities (EPA)s in ethics, with further exploration of the use of portfolios and key factors influencing its design, implementation and assessment of PIF and micro-credentialling in ethics practice.

Keywords: Postgraduate medical education, Physicians, Medical ethics, Ethics training program, Ethics education, Ethics curriculum, Scoping review, Systematic scoping review, SEBA

\section{Introduction}

Seen as a means of ensuring that "obligations of moral nature which govern the practice of medicine" [1] are maintained, ethics training amongst physicians have evolved to contend with ethical issues facing medical practice. Whilst basic levels of ethics knowledge and skills have been stipulated by accreditation bodies such as The Royal College of Physicians and Surgeons of Canada, The General Medical Council, the American Academy of Family Physicians (AAFP) and the Accreditation Council for Graduate Medical Education (ACGME), many ethics programs have struggled to keep pace with change whilst remaining sensitive to the demands of clinical practice. Inevitable variations in the content and duration of ethics education amongst physicians have been laid bare in a recent review pertaining to family physicians in residency programs in the United States [2].

The litmus test for effectively educating physicians in ethics knowledge, skills and professional conduct in a medical field trepidatious of legal recourse and struggling to meet public trust and societal expectations [3-7] has perhaps been the COVID-19 pandemic. Yet, the surfacing of reports of questionable physician conduct and clinical decisions during the COVID-19 pandemic also offers an opportunity to take stock of prevailing education programs, review gaps in content and structure of ethics education programs as well as update and instil more evidence based, clinically relevant, learner centred education initiatives.

\section{The need for this review}

To guide this process of retooling ethics education programs for physicians, a systematic scoping review is proposed to analyse current postgraduate medical ethics training and assessment programs in peer-reviewed literature.

\section{Methodology}

We adopt Krishna's systematic evidence-based approach (SEBA) to guide this systematic scoping review (henceforth SSRs in SEBA) [8-14] and scrutinise a broad range of literature [15-17]. With its constructivist perspective and relativist lens, SSRs in SEBA map the complex and diverse historical, socio-cultural, ideological and contextual factors that impact practice to provide a holistic picture of medical ethics training programs for graduates beyond medical school [17-24].

To further improve the reliability of the results, the research team consulted medical librarians from the Yong Loo Lin School of Medicine (YLLSoM) at the National University of Singapore (NUS) and the National Cancer Centre Singapore (NCCS), and local educational experts and clinicians at NCCS, Palliative Care Institute Liverpool, YLLSoM and Duke-NUS Medical School (henceforth the expert team). The Systematic Approach, Split Approach, Jigsaw Perspective, , Funnelling Process, and Discussion stages of SEBA (Fig. 1. The SEBA Process) were used to guide the entire research process.

\section{Stage 1: Systematic approach \\ Determining the title and background of the review}

The research team consulted the expert team and stakeholders from a local medical ethics training program to determine the overarching goals of the SSR in SEBA as well as the population, context and medical ethics training programs to be evaluated.

\section{Identifying the research question}

Guided by the Population, Intervention, Comparison and Outcome (PICOS) elements of the inclusion criteria [25], the primary research question is "How do postgraduate medical training programs teach ethical skills?" The secondary questions are "What are the core topics included?" and "What are the methods used to structure the program in postgraduate training?"

As part of the SEBA methodology's iterative process, when the initial results of this review were discussed, the expert team advised that a study of current methods of assessing ethics be conducted to address the lack of data on assessments of ethics education. Thus, a second SSR in SEBA was carried out. Similarly guided by PICOS, the primary research question is "How is ethics knowledge, skills, and competencies assessed in postgraduate training?" The secondary question is "What domains are assessed?" 


\section{Stage 5 \\ Discussion: Synthesis of SSR in SEBA}

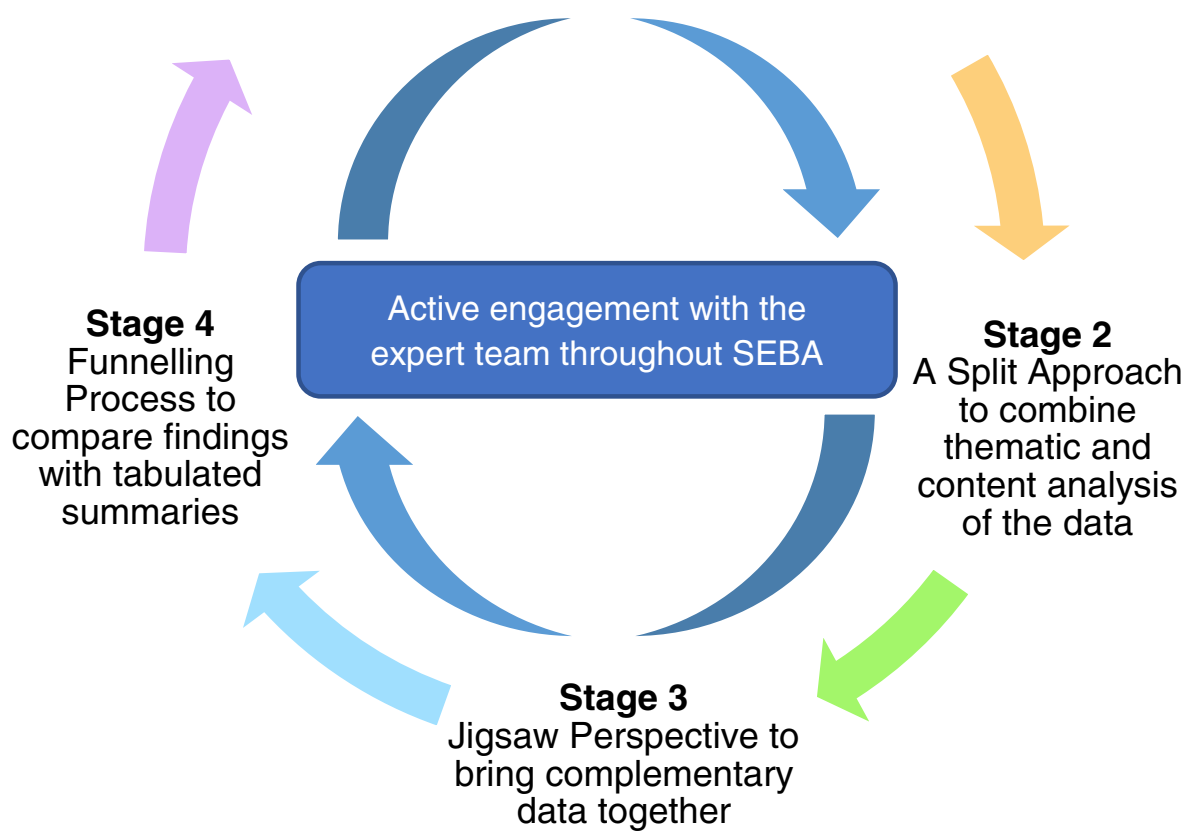

Stage 1

A Systematic Approach to search and select articles 
Table 1 PICOS, inclusion criteria and exclusion criteria applied to literature search on medical ethics training programs

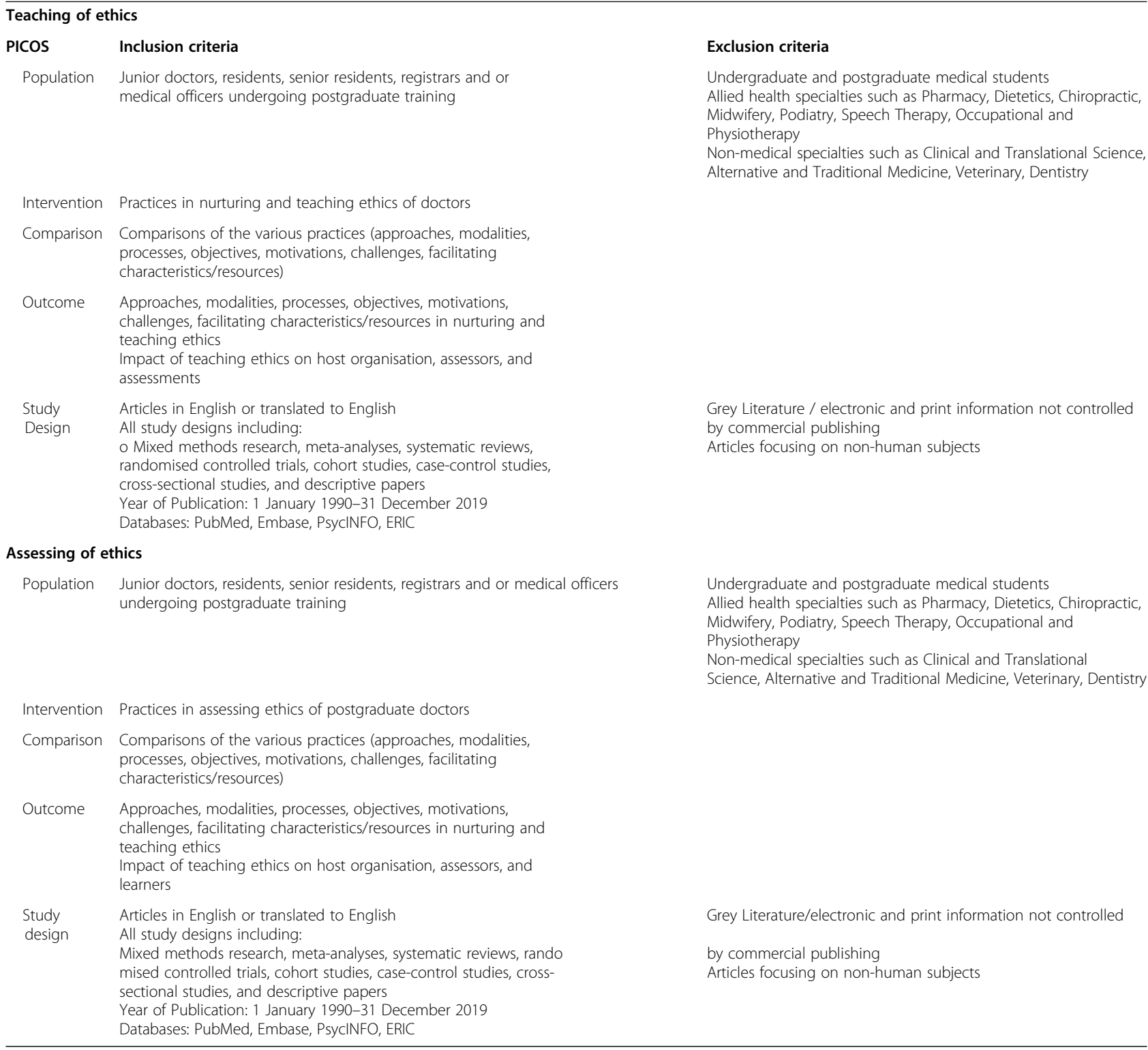

experiences and specialties whilst circumnavigating the context-specific nature of medical ethics in Medicine [29, 31-37]. It also accommodates for a wide range of research methodologies present amongst the included articles which prevents the use of statistical pooling and analysis [29, 38-42] and facilitates appropriate analysis of socio-culturally influenced educational processes such as medical ethics.

'Codes' were constructed from the 'surface' meaning of the text through a reiterative step-by-step thematic analysis. These were re-organised into themes that were best able to represent the data. They were reviewed individually and then as a group. Subsequently, the members of this sub-team deliberated their separate findings online and utilised 'negotiated consensual validation' to achieve consensus on the final themes.

\section{Hsieh and Shannon (2005)'s approach to directed content analysis}

Hsieh and Shannon's approach to directed content analysis was employed to increase the validity of the themes and to address Braun and Clarke's relative failure to engage contradictory data.

With regards to the teaching of ethics, the second sub-team drew codes and categories from Sutton [43]'s article entitled 'Ethics and law teaching and learning in undergraduate medicine' and McKneally and Singer [44]'s 'Bioethics for clinicians 25. Teaching bioethics in the clinical setting'. 


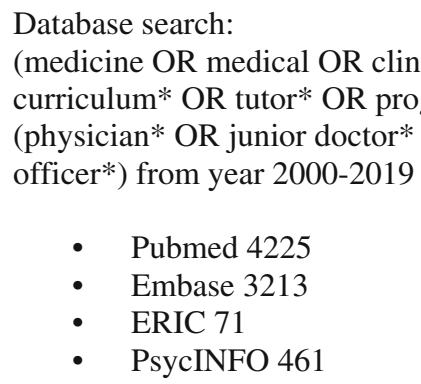

Total: 7970 articles

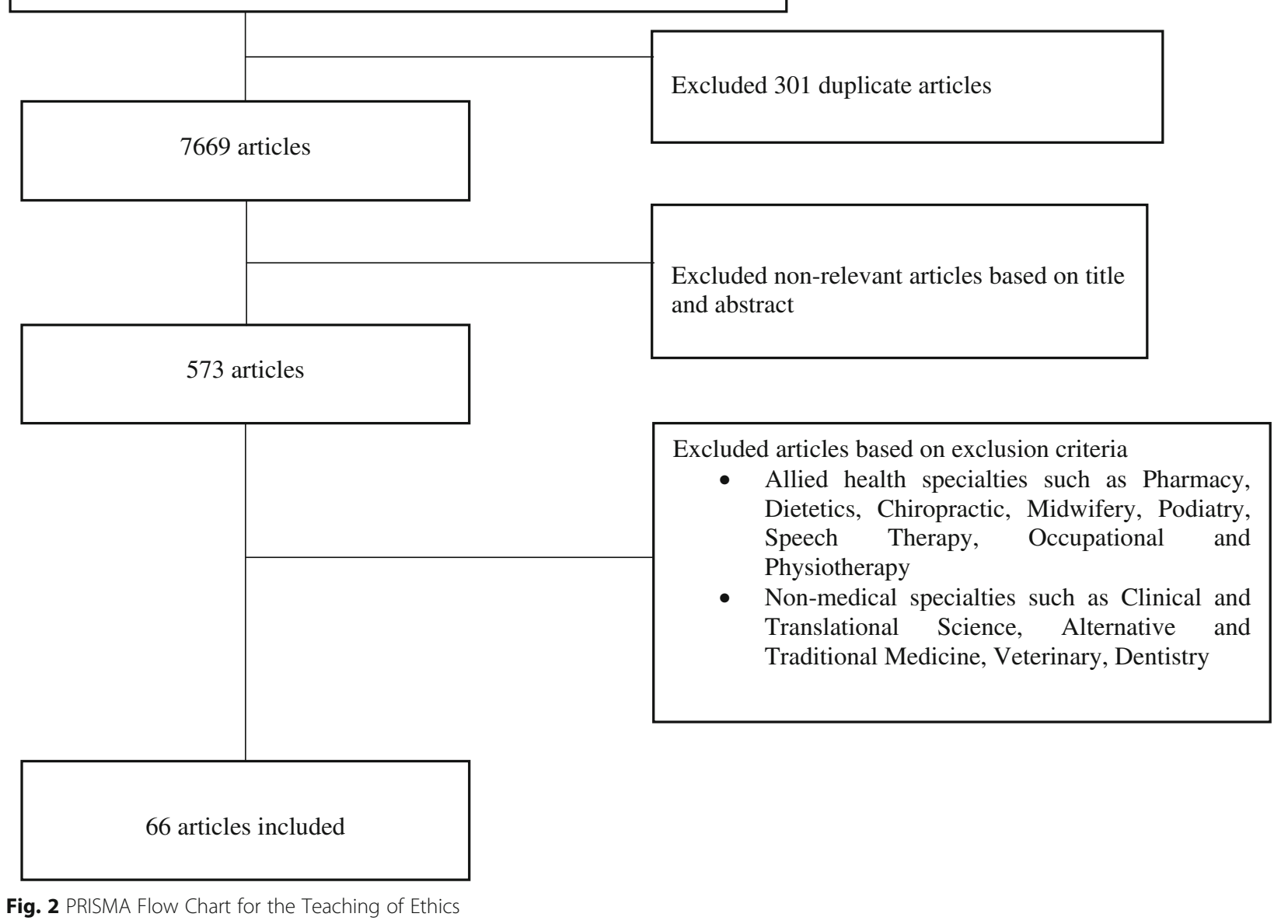

With regards to the assessing of ethics, codes and categories from Norcini, Anderson [35]'s 'Draft 2018 Consensus Framework for Good Assessment', Veloski, Boex [45]'s 'Systematic review of the literature on assessment, feedback and physicians' clinical performance: BEME Guide No. 7' and Watling and Ginsburg [46]'s 'Assessment, feedback and the alchemy of learning' were used.

These codes were adopted as a framework for reviewing the included articles. Any relevant data not captured by existing codes were assigned a new code through deductive category application. The independent findings were discussed online and 'negotiated consensual validation' was again used to achieve consensus on the final 'code book'.

\section{Stage 3: The jigsaw perspective}

The findings of the Split Approach and its reiterative process were then pooled together to ensure a wellrounded perspective of the data. Here, common themes and categories within each SSR were compared. Overlaps between the categories and themes were combined to create a wider perspective of the data, much like 
Database search:

(ethics) AND (physician* OR junior doctor* OR resident* OR registrar* OR medical officer*) AND (assessment) from year 1990-2019

- $\quad$ PubMed 8909

- Embase 108

- ERIC 644

- PsycINFO 258

Total: 9919 articles

Additional records identified through other sources:

0 article
Excluded duplicates and non-relevant articles based on title and abstract (e.g. not an assessment tool)

29 articles included

Fig. 3 PRISMA Flow chart for the assessing of ethics

bringing together complementary pieces of a jigsaw. This process is called the Jigsaw Perspective and is overseen by the expert team to ensure consistency.

\section{Results}

The first search involving the teaching of ethics retrieved 7669 abstracts, with 573 full-text articles reviewed and 66 articles included. Comparison of the categories and themes identified as part of the Split Approach revealed similar categories and themes which were combined into themes/categories using the Jigsaw Perspective. These themes/categories include the goals, content, teaching methods employed, and enablers and barriers to teaching ethics.

For the assessment of ethics, the search saw 9919 abstracts identified, 333 full-text articles reviewed and 29 articles included. The Split Approach from the SSR in SEBA of assessment methods revealed three themes/categories which included the types and domains assessed and the pros and cons of various assessment methods. 


\section{Stage 4: The funnelling process}

In addition, a third sub-team summarised and tabulated the included full-text articles to ensure that important concepts of discussion and contradictory views within the included articles were retained. The tabulated summaries also serve to verify that the results ascertained are an accurate representation of the existing data. The tabulated summaries for the teaching and assessing of ethics may be found in Additional File 2 and 3 respectively. Under the oversight of the expert team, the research team combined themes/categories from the two SSRs in SEBA based upon their similarities and their areas of overlap in keeping with the Funnelling Process.

The five funnelled themes/categories from the two searches are the goals and objectives, the content, pedagogy, enabling and limiting factors, and assessment tools.

\section{Goals and objectives}

The goals and objectives of ethics training programs for doctors are highlighted in Table 2 below.

Overall, the goal of most ethics programs was to refresh key ethical principles covered in medical schools [51], prepare physicians to tackle ethical dilemmas, and improve their confidence in doing so [59, 71, 77]. Some programs also introduced context and specialty-specific ethical dilemmas as highlighted in the next section on content covered [48, 53, 56, 70, 78-80].

\section{Content covered}

Content covered is outlined in Table 3.

Most training programs covered a varying number of topics.

Whilst Carrese, Malek [96] noted an overlap in the range of topics covered in ethics training for doctors and those for medical students, the authors explain that "educational materials offered to residents can typically be more complex and contextual than those intended for medical students, and ethical issues can be more nuanced and discussed in greater depth".

\section{Pedagogy}

The diverse pedagogies are highlighted in Table 4 below.

There is great variation in the timing and duration of such training sessions. Formal teaching run by the host organisation or institution tended to come in the form of mandatory training programmes $[80,81]$ that span the course of a few years [62, 82] or a single day [67]. Some programs are held over a few hours each year [58, 94], or each month or every few months as part of a wider residency training program $[49,59,83]$.

Informal programs tended to be situated in more informal settings where refreshments are served and hierarchies are minimised $[49,59]$.

Different training programs utilised a combination of approaches to meet their objectives [82]. At the University of Toronto, Howard, McKneally [70]

Table 2 Goals and objectives of ethics training programs

\begin{tabular}{ll}
\hline Goal & Objective \\
\hline Build Knowledge & To understand the historical background and definition of ethics [47, 48], social science, philosophy, religion and \\
& law and their relevance to clinical care [49-51]. \\
& To gain knowledge and awareness of ethics issues relevant to individual practices in the course of patient care \\
& {$[47,49,51-58]$.} \\
& Improve problem-solving skills by thinking critically and systematically when an ethical dilemma arises such as \\
Improve Skills & by providing opportunities for doctors to discuss ethical dilemmas [47-49, 51-53, 55, 57, 59-62] \\
& Appreciate the socio-cultural nuances and individual circumstances of the patient and/or their family in the \\
& Context of the ethical dilemma [60, 62]. \\
& Develop interpersonal skills to resolve ethical conflicts [48, 50, 55, 63-65]. \\
& Reduce likelihood of physician making an ethical error or legal error [49, 50, 52]. \\
& Overall, improve patient care and clinical decision making and adherence to ethical guidelines as part of \\
& research [50, 60, 66, 67]. \\
& Develop appropriate attitudes, values that facilitate ethical conduct [68] [57, 58]. \\
& Maintain high level of professionalism and ethical practice [49, 54]. \\
Change Attitudes and & Increase self-awareness and understanding of professional boundaries [48, 49, 52]. \\
Professional Identity & Prevent cynicism and detachment in patient interaction and gainincrease job satisfaction [48, 50, 52, 64]. \\
& Help doctors become good teachers and future role models [69, 70]. \\
& Sustain and improve accountability to public [69, 70] to fulfil physicians' ethical and service obligations [49, 60, 70,76]. \\
Fulfil Duty to Society &
\end{tabular}


Table 3 Domains of content covered in ethics training programs

\begin{tabular}{|c|c|c|}
\hline Domains & Subdomains/Topics & References \\
\hline \multicolumn{3}{|l|}{ Basic Principles of Ethics } \\
\hline Ethical Theories and the Hippocratic Oath & - & [80] \\
\hline Respect for Patient and Autonomy & $\begin{array}{l}\text { Privacy and confidentiality } \\
\text { Disclosure or non-disclosure to patients } \\
\text { Informed consent } \\
\text { Decision-making capacity and surrogate decision-making } \\
\text { Informed refusal of medical interventions } \\
\text { Informed consent in minors }\end{array}$ & $\begin{array}{l}{[47,49,52,53,65} \\
78,80-89]\end{array}$ \\
\hline Beneficence and Non-Maleficence & $\begin{array}{l}\text { Medical failures and errors such as problems associated with the transfer of care } \\
\text { Truth-telling }\end{array}$ & {$[49,53,58,83,87]$} \\
\hline Justice & $\begin{array}{l}\text { Access to healthcare } \\
\text { Healthcare disparities } \\
\text { Healthcare system } \\
\text { Allocation of scarce resources }\end{array}$ & $\begin{array}{l}{[53,58,60,83-85,} \\
89]\end{array}$ \\
\hline Care at End-of-Life & $\begin{array}{l}\text { Patient advance directives } \\
\text { Withholding and withdrawing life-sustaining interventions, medical futility } \\
\text { Care for the dying, palliative versus curative care } \\
\text { Determination of death }\end{array}$ & $\begin{array}{l}{[59,65,73,78,81} \\
84,86]\end{array}$ \\
\hline Communication Skills and Competencies & $\begin{array}{l}\text { Patient communication such as breaking bad news, or communication of adverse } \\
\text { outcomes } \\
\text { Interprofessional communication } \\
\text { Conflict resolution }\end{array}$ & $\begin{array}{l}{[49,54,60,65,74,} \\
75,82,85,89-93]\end{array}$ \\
\hline Doctor-Patient Relationship & $\begin{array}{l}\text { This may include understanding day-to-day interactions with patients and how one } \\
\text { should conduct themselves professionally or may tackle specific circumstances such as } \\
\text { the acceptance of gifts from patients. Doctors are also taught how to navigate conflicts } \\
\text { of interest. }\end{array}$ & $\begin{array}{l}{[49,54,58,60,80,} \\
82,84]\end{array}$ \\
\hline Ethics and Law & This may cover medicolegal issues such as with regards to expert witness testimony & {$[84,92,94]$} \\
\hline Ethics and Philosophy & - & [61] \\
\hline \multicolumn{3}{|l|}{ More Specialised Content } \\
\hline $\begin{array}{l}\text { Application of Ethics in consideration of } \\
\text { Sociocultural Nuances and Particular } \\
\text { Circumstances of Patients }\end{array}$ & $\begin{array}{l}\text { This may involve being, in general, well equipped to tackle communication challenges } \\
\text { due to cultural differences. It may also include family relationships of patients and } \\
\text { employment status. }\end{array}$ & {$[58-60,86]$} \\
\hline Research Ethics & $\begin{array}{l}\text { Publication ethics } \\
\text { Ethical issues in human subject research or in research involving vertebral animals } \\
\text { Good clinical practice in research } \\
\text { The use of placebos }\end{array}$ & $\begin{array}{l}{[48,49,54,66,70,} \\
85]\end{array}$ \\
\hline $\begin{array}{l}\text { With Regards to Medical Trainees, or being a } \\
\text { Resident }\end{array}$ & $\begin{array}{l}\text { Disclosure of trainee status } \\
\text { Tension between education and best care for patients } \\
\text { Hidden curriculum } \\
\text { Moral distress }\end{array}$ & {$[49,52,60,90]$} \\
\hline Specialty-specific Ethical Dilemmas & $\begin{array}{l}\text { Neonatal, perinatal and paediatric care "ethics of consent and [law] regarding minors } \\
\text { with the legal authority to consent." } \\
\text { Surgery, cosmetic surgery such as how to take informed consent for surgical } \\
\text { procedures } \\
\text { Genetics } \\
\text { Psychiatry, such as on psychiatry diagnoses, suicide, consultation liaison psychiatry } \\
\text { Organ donation } \\
\text { Dermatology such as "cultural and religious determinants of dermatologic health care" } \\
\text { Infectious diseases such as treatment of highly contagious disease, vaccination and } \\
\text { bioterrorism } \\
\text { Obstetrics and gynaecology, such as adolescent sexuality, domestic violence and abuse, } \\
\text { termination of pregnancy, maternal-fetal conflict, assisted reproduction and paternal } \\
\text { rights }\end{array}$ & $\begin{array}{l}{[49,58,59,62,65} \\
78,83,84,95]\end{array}$ \\
\hline Interactions with Society at Large & $\begin{array}{l}\text { With vendors } \\
\text { With the pharmaceutical industry such as in issues of drug pricing } \\
\text { With the media and advertising }\end{array}$ & $\begin{array}{l}{[49,54,80,84,85,} \\
91]\end{array}$ \\
\hline Relationship with Healthcare Institute & $\begin{array}{l}\text { Negotiation of contract } \\
\text { Whistle blowing }\end{array}$ & {$[49,54]$} \\
\hline
\end{tabular}


Table 4 Pedagogy employed

\begin{tabular}{|c|c|c|}
\hline Domains & Elaboration & References \\
\hline Case-based approach & $\begin{array}{l}\text { Case-based approaches may be integrated into many of the approaches below. } \\
\text { An example of how a case-based approach may be utilised is through } \\
\text { videotaped consultation or significant event analysis as presented by Chandra } \\
\text { et al. (2017 and Oljeski et al. (2004). } \\
\text { Sim et al. (2015) and Goodrich, Irvine, and Boccher-Lattimore (2005) interestingly } \\
\text { used narratives in their teaching to showcase the human element at the centre } \\
\text { of ethical dilemmas. } \\
\text { Roberts et al. (1996) in describing their work on ethics teaching in psychiatry, } \\
\text { mention a six step approach to ethical cases, from defining the case to creating } \\
\text { context for reflection and review. }\end{array}$ & $\begin{array}{l}{[48,50,51,56,57,59,67,} \\
73,81,82,86,97,98]\end{array}$ \\
\hline Online ethics modules & $\begin{array}{l}\text { These may be made available for interested learners to utilisel in their own free } \\
\text { time. } \\
\text { However, Jain et al. (2011) highlight that the "value of web-based approaches } \\
\text { warrants further investigation". }\end{array}$ & {$[50,85,89]$} \\
\hline $\begin{array}{l}\text { Lectures and Seminar Sessions which } \\
\text { may be termed as "Grand Rounds" }\end{array}$ & $\begin{array}{l}\text { Such methods are more didactic, with key speakers who might be experts in the } \\
\text { field sharing information on ethics principles. }\end{array}$ & {$[65-67,78,81,88,92,94]$} \\
\hline Group Discussions & $\begin{array}{l}\text { Such as on key ethical issues or cases, and may serve as a platform for learners } \\
\text { to voice their opinions, values and uncertainties. There might be a faculty leader } \\
\text { present to guide discussion. }\end{array}$ & $\begin{array}{l}{[49,50,58,59,65,73,86,} \\
94,99]\end{array}$ \\
\hline Research Opportunities & In these, students are given the opportunity to carry out research projects. & [100] \\
\hline Hands-on Practice & $\begin{array}{l}\text { Doctors may be asked to apply their ethical knowledge and practice } \\
\text { demonstrating ethical competencies through the use of: } \\
\text { Simulation } \\
\text { - Role Play } \\
\text { - Practice with Standardized Patients } \\
\text { A case-based approach may be used in conjunction with hands-on practice. }\end{array}$ & {$[58,69,74,78,86,99]$} \\
\hline Reflective Practice & $\begin{array}{l}\text { This may be achieved through: } \\
\text { Writing, editing and publishing deliberation on ethical issues } \\
\text { - Writing and reading poetry and pieces of written work related to doctors and } \\
\text { patients }\end{array}$ & {$[56,69,99]$} \\
\hline Observation and Shadowing & $\begin{array}{l}\text { Learners may be invited to family meetings, ethics consultation and inpatient } \\
\text { rounds where they observe a careful consideration of ethics being integrated } \\
\text { into clinical decision-making. }\end{array}$ & {$[72,99]$} \\
\hline Role-modelling & $\begin{array}{l}\text { Jain et al. (2011)'s survey on ethics teaching on psychiatry residents elucidated } \\
\text { that the teaching was more memorable if learners were treated ethically by their } \\
\text { teachers. }\end{array}$ & {$[50,70,97]$} \\
\hline Bedside teaching & These are tutorials carried out by tutors by the bedside. & {$[69,70]$} \\
\hline $\begin{array}{l}\text { Master Programs in Medical Ethics or } \\
\text { Fellowships }\end{array}$ & These are formal certification programmes in the field of Medical Ethics. & {$[62,70]$} \\
\hline Educational Portfolios & $\begin{array}{l}\text { Portfolios may be utilised in conjunction with mentorship in order to improve } \\
\text { self-reflection. }\end{array}$ & {$[63,69]$} \\
\hline Mentoring Programs & These mentoring programs may be informal or formal. & {$[63,69,94]$} \\
\hline
\end{tabular}

describes integrating formal bioethics teaching with "role modelling of ethical behaviour and bedside teaching around ethical issues". The impact of this combination is echoed by Lang, Smith [97]'s survey of paediatric programme directors on how ethics is taught. Carrese, Malek [96]'s literature review of medical ethics training similarly highlighted the synergistic nature of the formal, informal and hidden curricula [77].

Other authors have proffered the use of a multidisciplinary approach to illustrate the intricacies of team based working in the healthcare setting $[59,69,73,101,102]$.

\section{Enabling factors and barriers}

Enabling factors and barriers to the successful execution of ethics training programs may present themselves as follows (Table 5):

Believing that new learners often "do not appreciate the practical side of ethical conflicts as they have had limited exposure to clinical medicine or have not yet fully formed a professional identity with its associated values," Grace and Kirkpatrick [68] piloted ethical vignettes and ethical reasoning technique to acculturate ethical thinking into practice. Howard, McKneally [84]'s study of surgical resident's attitudes 
Table 5 Enabling factors and barriers to ethics training programs

\section{Enabling factors \\ Learning Environment \\ Safe environment \\ Strong role modelling \\ Curricular Design and Implementation \\ Clear learning objectives \\ Allow for preparatory work \\ Reflective practice \\ Practice-oriented \\ Support from Host Institute \\ Training programs for teachers \\ Devoted educational or health institute, manpower and resources}

\section{Barriers}

Learning Environment

Poor role models

Curricular Design and Implementation

Lack of structured curricula

Lack of time and/or opportunity for formal ethics and professionalism instruction

Difficulties in adapting and improving curricula in response to increased sensitivity to ethical concerns

Lack of an agreed framework that ethics curricula can be designed from and adapted to local settings

Barriers from Host Institute

Unsupportive institutional culture towards ethics teaching

Learner Factors

Poor attitude and resistance to learning

\section{Elaboration}

References

A non-judgemental, safe space inspires reflection, sharing and peerlearning.

Having instructors who are close in age may allow for more open, honest discussions that promote ethical understanding due to the lack of hierarchy.

Good role models who demonstrate ethical behaviour and good professional conduct consistently at work promote the success of ethics training.

Clear objectives guide learning and assessment.

$[50-52,86]$

Students should be given learning materials early.

This refers to good attitudes on the part of the student to engage in reflection, such as through the use of narratives.

The programs should also be practice-oriented and relevant to doctors, such as by highlighting ethical issues faced in real life.

$[51,52,82,111]$

This includes teacher workshops to assist teachers in developing curricula and acquiring appropriate and relevant teaching skills.

This may include dedicated ethics experts responsible for teaching, and expert input in the design of curricula.

\section{Elaboration}

References

This may include a culture of bullying and other unethical behaviour exhibited by negative role models.

This may lead to important topics not being identified or covered. This could also be due to curricular crowding leading to sacrifices in the ethics curriculum.

$[79,80,112]$

Lack of time was identified as a key limitation for tutors to provide teaching $[52,55,59,60$ and for students to attend such teaching due to competing demands.

This may lead to outdated curricula. $73,79,83,96-$ 98]

$[103,113]$

This may thus lead to difficulty in adapting curricula to be relevant to the unique ethics situations in different hospitals or different specialties.

$[62,81]$

This may result in having unwilling, underprepared, undertrained teachers

$[51,79,87,96$ $98,103,114]$

This refers to students who do not seek to improve or are unwilling to be open to ethical discussions or challenge their current understandings and

$[51,83,97,98]$ perceptions.

towards ethics teaching revealed a general sense of being poorly prepared and relatively inexperienced for case discussions and practical application of ethical issues.

Carrese, McDonald [60] and Chandra, Ragesh [69] also note that even in the event that ethical issues did arise, they were poorly modelled and rarely used as teaching moments.

\section{Assessment tools}

Assessment tools comprise the type of assessment method employed, corresponding domains assessed and 
Table 6 Types of assessment methods, domains assessed, advantages, disadvantages

\begin{tabular}{|c|c|c|c|c|}
\hline & $\begin{array}{l}\text { Assessment } \\
\text { methods }\end{array}$ & Domains assessed & Advantages & Disadvantages \\
\hline $\begin{array}{l}\text { May be integrated } \\
\text { into one of the } \\
\text { methods that follow: }\end{array}$ & $\begin{array}{l}\text { Clinical scenarios } \\
{[72,115-119]}\end{array}$ & $\begin{array}{l}\text { Identification of ethical issues } \\
\text { Creation of a plan to navigate the ethical } \\
\text { issue } \\
\text { Rationalisation of decision with ethical } \\
\text { principles, moral values } \\
\text { Real-life anecdotes }\end{array}$ & $\begin{array}{l}\text { Application in 'real life' } \\
\text { scenarios without direct } \\
\text { observation }\end{array}$ & $\begin{array}{l}\text { Subject to varied } \\
\text { interpretations }\end{array}$ \\
\hline Knows & $\begin{array}{l}\text { MCQs } \\
{[72,120-122][123,} \\
124][89]\end{array}$ & $\begin{array}{l}\text { Assessment of learner's ethical knowledge } \\
\text { Comparison of knowledge before and after } \\
\text { teaching } \\
\text { Clinical scenario-based MCQ }\end{array}$ & $\begin{array}{l}\text { Could be employed as } \\
\text { formative and summative } \\
\text { assessments } \\
\text { Unbiased } \\
\text { Trustworthy } \\
\text { Less time needed for } \\
\text { grading and picks up areas } \\
\text { for improvement }\end{array}$ & $\begin{array}{l}\text { Only looks at content } \\
\text { knowledge } \\
\text { Tough to present clinical } \\
\text { situations in a practical, } \\
\text { multi-perspective way }\end{array}$ \\
\hline Knows, Knows How & $\begin{array}{l}\text { Essays } \\
{[72,121,124-126]}\end{array}$ & $\begin{array}{l}\text { Assessment of knowledge application } \\
\text { through a clinical scenario-based essay }\end{array}$ & $\begin{array}{l}\text { Could be employed as } \\
\text { formative and summative } \\
\text { assessments }\end{array}$ & $\begin{array}{l}\text { Not able to evaluate } \\
\text { holistically }\end{array}$ \\
\hline Knows, Knows How & $\begin{array}{l}\text { SAQs } \\
{[73,126]}\end{array}$ & $\begin{array}{l}\text { Evaluation of knowledge } \\
\text { Allowance of deeper reflections and } \\
\text { analysis assessments }\end{array}$ & $\begin{array}{l}\text { Focus on distinct areas } \\
\text { Able to identify areas for } \\
\text { improvement }\end{array}$ & $\begin{array}{l}\text { Inability to apply } \\
\text { knowledge effectively } \\
\text { Takes a lot of time for } \\
\text { both student and teacher }\end{array}$ \\
\hline $\begin{array}{l}\text { Knows How, Shows } \\
\text { How }\end{array}$ & $\begin{array}{l}\text { Debates } \\
\text { [119] }\end{array}$ & Includes different stakeholder roles & $\begin{array}{l}\text { Offers a relevant clinical } \\
\text { context }\end{array}$ & $\begin{array}{l}\text { Focuses upon assessing } \\
\text { intermediate/ advanced } \\
\text { skills and abilities }\end{array}$ \\
\hline Shows How, Does & $\begin{array}{l}\text { Observations }[72, \\
120,125,127,128] \\
{[126,129,130]}\end{array}$ & $\begin{array}{l}\text { May be incorporated as part of an } \\
\text { Objective Structured Clinical Examination } \\
\text { (OSCE) or evaluation in clinical settings } \\
\text { May include a 360-degree evaluation } \\
\text { Evaluation of ability to apply content, } \\
\text { identification of ethical concerns, ability to } \\
\text { analyse and rationalise decisions } \\
\text { Individualised feedback from patients and/ } \\
\text { or simulated patients, tutors and medical } \\
\text { professionals }\end{array}$ & $\begin{array}{l}\text { Identifies areas for } \\
\text { improvement in clinical/ } \\
\text { practical settings } \\
\text { Identifies biases, lapses in } \\
\text { professionalism and } \\
\text { deficiencies with techniques } \\
\text { Able to provide instant } \\
\text { feedback } \\
\text { Able to offer productive } \\
\text { educational experiences } \\
\text { Encourages the learning of } \\
\text { knowledge in relevant } \\
\text { clinical situations } \\
\text { Facilitates longitudinal } \\
\text { assessment } \\
\text { Reliability amongst inter- } \\
\text { raters }\end{array}$ & $\begin{array}{l}\text { Inadequate predictive } \\
\text { validity } \\
\text { Requires a lot of resources } \\
\text { (e.g. time, staff) } \\
\text { Subjectivity in simulated } \\
\text { patients }\end{array}$ \\
\hline Not specified & $\begin{array}{l}\text { Self-assessment } \\
{[128]}\end{array}$ & $\begin{array}{l}\text { Portfolios provide a longitudinal } \\
\text { perspective } \\
\text { Evaluation of ability to apply content, } \\
\text { identification of ethical concerns, ability to } \\
\text { analyse and rationalise decisions }\end{array}$ & $\begin{array}{l}\text { Allows for reflection } \\
\text { Popular amongst users and } \\
\text { institutions } \\
\text { Accurately assesses } \\
\text { competencies and learning } \\
\text { Good for self-driven learners } \\
\text { Learning is documented } \\
\text { Various media input } \\
\text { Feedback from various } \\
\text { stakeholders improves } \\
\text { validity }\end{array}$ & $\begin{array}{l}\text { Tough to establish } \\
\text { compliance } \\
\text { Training is needed }\end{array}$ \\
\hline
\end{tabular}

their pros and cons (Table 6). These assessment methods may be mapped onto the Miller's pyramid of clinical competency [131].

\section{Stage 5: Discussion and synthesis of SSRs in SEBA}

A review of the results and consultation with local educationalists, clinicians and researchers experienced in medical ethics teaching and assessment reiterated the completeness of this review. The narrative produced was guided by the STORIES (Structured approach to the Reporting In healthcare education of Evidence Synthesis) statement [38] and Best Evidence Medical Education (BEME) Collaboration guide [39].This novel review of teaching and assessment of ethics amongst physicians 
reveals a number of insights. Here we list some of the key findings for ease of reference and will delve into three areas of particular interest.

- The common objective across most ethics programs is to improve awareness of ethical principles and skills in resolving ethical dilemmas tactfully and professionally. More recent articles however focused on changing practice, shaping attitudes and meeting social and professional obligations.

- Recent accounts of teaching and assessing ethics reveal the impact of context and speciality related influences.

- The core elements of most programs concerned the four principles of autonomy, beneficence, nonmaleficence and justice; the doctor- patient relationship; communication; and end of life care.

- Speciality or context specific information contents include research ethics; speciality related topics; trainee related considerations and social and or institutional interactions.

- There were a number of approaches employed to teach ethics yet all were focused upon providing learners with an opportunity to apply their knowledge in a variety of ways, ranging from optional participation in group discussions to guided case discussions and reflections.

- Factors facilitating ethics education and assessments were a structured program, a nurturing culture and a safe environment to discuss concerns and enquiries.

- Important in ethics training are role modelling, casebased discussions and instruction on ethical sensitivity and resolving ethical issues.

- There is a general lack of assessment methods.

While there are inherent differences to each of the training programs, they may be seen to lie on a continuum of guiding the learner from knowledge building to practice and ultimately to nurturing the learner's professional identity. Indeed, many programs seek to prepare learners for their societal responsibilities $[49,60,70-76,85]$ and their membership to their 'community of practice' $[69,70]$. This would be consistent with Cruess, Cruess [131]'s "Is" level at the apex of their amended Miller's pyramid. With this in mind, evidence for this posit is visible from the contents and manner that ethics education is taught.

Careful study of the longitudinal nature of training programs, the presence of refresher sessions and/or sessions involving 'core' topics such as autonomy, beneficence, non-maleficence, justice, end of life care, the doctor patient relationship and the duty of care suggests a reinforcement of prevailing knowledge [48,
$50,51,56,57,59,67,73,81,82,86,97,98]$. The introduction of more specialised speciality, clinical and research content suggests a layering of new knowledge and experiential learning. This process of building on prevailing knowledge evidences the longitudinal nature of training that would seem to build on training received in medical school and efforts to deepen appreciation of ethical issues in the clinical setting. This is also evidenced by the methods used to train the learners. Here didactic lectures, online videos and bedside ethics discussions give way to case discussions and presentations, allowing the learner to build their knowledge and confidence and apply their knowledge and skills in addressing the ethical issues [58, 69, 74, 78, 86, 99].

These considerations also highlight the vertical aspect of the spiral curriculum employed by most programs and raise the importance of knowledge and skills assessments. Evidence that ethical training is introduced at specific stages of practice such as during postings where end of life care is especially relevant, or where discussions of withdrawing and withholding life sustaining treatment, such as intensive care placements, suggest horizontal integration of the ethics training programs.

The presence of a spiral curriculum that seeks to build on prevailing knowledge and integrate context specific learning highlights two considerations. The first is the use of pertinent assessments to determine progress to the next stage of the training and the second is the support of the program by the host organizsation.

Training should be followed by assessments to ensure that knowledge has been effectively assimilated and applied appropriately, and to facilitate microcredentialling, as suggested by Norcini [132]. In tandem with this, there is also the need to establish clear Entrustable Professional Activities (EPA) s in ethics education which, at present, will require further research and consideration given the diversity of practice, specialities, socio-cultural considerations and learner variability in terms of their prevailing knowledge, skills, attitudes and experience [133]. The need for a longitudinal assessment process as a part of an education portfolio and their impact on the development of professional identity formation (PIF) also demands closer scrutiny [131, 134].

Here, learning portfolios will allow seamless integration between ethics training in undergraduate and postgraduate training $[51,83,97,98]$ and would be in keeping with the notion of ethics training being part of a longitudinal training experience $[4,135]$ that nurtures PIF $[131,134]$. Portfolios not only serve as a valuable assessment modality for longitudinal evaluation of ethical competency but also promotes continuous self-learning through the recognition of knowledge deficits while reinforcing good behaviour [63, 136-143]. 
Yet an effective ethics training program requires support fromresidency programs, healthcare institutes and educational institutes through the allocation ofallocating dedicated resources, manpower and faculty training [64, 70, 79]. The host organisation must orchestrate this training and provide careful oversight of the program's trajectory. Perhaps just as important is that there are efforts to ensure that clinicians acknowledge and adopt their roles and responsibilities in their 'communities of practice' [144]. The topics chosen should be practical and feasibly covered within the limited time allotted yet be relevant to clinical practice $[52,55,59,60,73,79$, 83, 96-98].

The programs and host organisations must also instil a nurturing ethical climate through the dissemination of core values and introduction of infrastructure that "proactively incorporates these values in the daily life of the healthcare organi[z]ations" [145]. An ethical climate would aid in professional identity formation [131, 134, 146].

\section{Limitations}

Whilst it was our intention to appreciate the range of available literature on ethics education in postgraduate medical education, it is evident that each paper could be studied in greater depth. This limitation is mainly due to incomplete reporting of the current training approaches and their curriculum, as well as the way in which the programs are is carried out and evaluated.

Furthermore, the range of selected articles chosen originates from papers that were largely written in North America and Europe. This limits the applicability of these findings, as the different cultures across the different geographical boundaries are not accounted for.

However, despite these limitations, this scoping review was carried out with the necessary rigour and transparency advocated by Arksey and O'Malley [21], Pham, Rajic [26], and Levac, Colquhoun [147]. The use of Endnote, a bibliographic manager, ensured that all the citations from the different databases were properly accounted for.

\section{Conclusion}

We believe the analysis of our findings in this scoping review will be relevant to educators and program designers in postgraduate medical settings around the world. However, the lack of consensus and difference in perspectives regarding the approach, content and quality assessments as well as the need to explore the inherent link amongst ethics, communication and professionalism $[63,148,149]$ justifies inclusion of programs focused on enhancing communication skills and professionalism in medicine. In addition, more needs to be done to research on establishing EPAs in ethics amidst the diverse characteristics of learners, their settings and their levels of experience as well as the particular healthcare system and culture that they practice in. Research should also look into portfolio design, implementation and assessment of PIF and micro-credentialling in ethics practice in the postgraduate setting.

\begin{abstract}
Abbreviations
COVID-19: Coronavirus disease 2019; EPA: Entrustable professional activities; SEBA: Systematic evidence-based approach; SSR: Systematic scoping review; YLLSoM: Yong Loo Lin School of Medicine; NUS: National University of Singapore; NCCS: National Cancer Centre Singapore; PICOS: Population, Intervention, Comparison and Outcome; STORIES: Structured approach to the reporting in healthcare education of evidence synthesis; BEME: Best evidence medical education; PIF: Professional identity formation
\end{abstract}

\section{Supplementary Information}

The online version contains supplementary material available at https://doi. org/10.1186/s12909-021-02644-5.

Additional file 1. Full PubMed Search Strategy.

Additional file 2. Tabulated Summaries for Teaching of Ethics.

Additional file 3. Tabulated Summaries for Assessing of Ethics.

\section{Acknowledgements}

The authors would like to dedicate this paper to the late Dr. S Radha Krishna whose advice and ideas were integral to the success of this study. The authors would like to thank the anonymous reviewers whose advice and feedback greatly improved this manuscript.

\section{Authors' contributions}

DZH, JLG, ZYO, JJQT, MKW, JW, XHT, RQET, CLLC, CWHN, JCKN, YTO, CWSC, KTT, LHST, GLGP, WF, LW, SHSN, ASIL, MC, AMCC, LKRK were involved in research design and planning, investigation, analysis, reflection, manuscript writing and review, and administrative work for journal submission. All authors have read and approved the manuscript.

Funding

No funding was received for this review.

Availability of data and materials

All data generated or analysed during this review are included in this published article [and its additional files].

\section{Declarations}

Ethics approval and consent to participate NA

\section{Consent for publication}

NA

Competing interests

The authors declare that they have no competing interests.

\section{Author details}

${ }^{1}$ Yong Loo Lin School of Medicine, National University of Singapore, NUHS Tower Block, 1E Kent Ridge Road, Level 11, Singapore 119228, Singapore.

${ }^{2}$ Division of Supportive and Palliative Care, National Cancer Centre Singapore, 11 Hospital Cr, Singapore 169610, Singapore. ${ }^{3}$ Duke-NUS Medical School, National University of Singapore, 8 College Rd, Singapore 169857, Singapore. ${ }^{4}$ Department of Rheumatology and Immunology, Singapore General Hospital, 16 College Road, Block 6 Level 9, Singapore General Hospital, Singapore 169854, Singapore. ${ }^{5}$ Department of Infectious Diseases, Singapore General Hospital, Outram Road, Singapore 169608, Singapore. ${ }^{6}$ Division of Cancer Education, National Cancer Centre Singapore, 11 Hospital Cr,

Singapore 169610, Singapore. ${ }^{7}$ Medical Library, National University of 
Singapore Libraries, Blk MD6, Centre, 14 Medical Dr, \#05-01 for Translational Medicine, Singapore 117599, Singapore. ${ }^{8}$ Palliative Care Institute Liverpool, Cancer Research Centre, University of Liverpool, 200 London Rd, L3 9TA Liverpool, UK. ${ }^{9}$ Centre of Biomedical Ethics, National University of Singapore, 21 Lower Kent Ridge Rd, Singapore 119077, Singapore. ${ }^{10} \mathrm{PalC}$, The Palliative Care Centre for Excellence in Research and Education, PalC c/o Dover Park Hospice, 10 Jalan Tan Tock Seng, Singapore 308436, Singapore.

\section{Received: 21 November 2020 Accepted: 30 March 2021} Published online: 09 June 2021

\section{References}

1. Brunt PW. Dictionary of medical ethics (2nd edn). Edited by A. S. Duncan, G. R. Dunstan and R. B. Welbourn. (Darton, Longman and Todd, London, 1981.) $£ 12.50$. - Contemporary issues in biomedical ethics. Edited by J. W. Davis, B. Hoffmaster and S. Shorten. (Humana press, Clifton, New Jersey, 1981.) £11. 15. J Biosoc Sci. 1982;14(3):374-6.

2. Manson HM, Satin D, Nelson V, Vadiveloo T. Ethics education in family medicine training in the United States: a national survey. Fam Med. 2014; 46(1):28-35.

3. Campbell AV. The teaching of medical ethics. Med Teach. 2011;33(5):349-50. https://doi.org/10.3109/0142159X.2011.571728.

4. Eckles RE, Meslin EM, Gaffney M, Helft PR. Medical ethics education: where are we? Where should we be going? A review. Acad Med. 2005;80(12): 1143-52. https://doi.org/10.1097/00001888-200512000-00020.

5. Millstone M. Teaching medical ethics to meet the realities of a changing health care system. J Bioeth Inq. 2014;11(2):213-21. https://doi.org/10.1007/ s11673-014-9520-9.

6. Pellegrino ED. Teaching medical ethics: some persistent questions and some responses. Acad Med. 1989;64(12):701-3. https://doi.org/10.1097/ 00001888-198912000-00002.

7. Sokol DK. Teaching medical ethics: useful or useless? BMJ. 2016:i6415.

8. Kow CS, Teo YH, Teo YN, Chua KZY, Quah ELY, Kamal N, et al. A systematic scoping review of ethical issues in mentoring in medical schools. BMC Med Educ. 2020;20(1):246. https://doi.org/10.1186/s12909-020-02169-3.

9. Bok C, Ng CH, Koh JWH, Ong ZH, Ghazali HZB, Tan LHE, et al. Interprofessional communication (IPC) for medical students: a scoping review. BMC Med Educ. 2020;20(1):372. https://doi.org/10.1186/s12909-020-02296-X.

10. Ngiam LXL, Ong YT, Ng JX, Kuek JTY, Chia JL, Chan NPX, et al. Impact of caring for terminally ill children on physicians: a systematic scoping review. Am J Hosp Palliat Care. 2020;1049909120950301.

11. Krishna LKR, Tan LHE, Ong YT, Tay KT, Hee JM, Chiam M, et al. Enhancing mentoring in palliative care: an evidence based mentoring framework. J Med Educ Curric Dev. 2020;7:2382120520957649.

12. Nur Haidah Ahmad Kamal LHET, Wong RSM, Ong RRS, Ryan Ern Wei Seow EKYL, Mah ZH, Chiam M, et al. Enhancing education in palliative medicine: the role of systematic scoping reviews. Palliat Med Care Open Access. 2020; 7(1):1-11.

13. Ryan Rui Song Ong REWS, Wong RSM. A systematic scoping review of narrative reviews in palliative medicine education. Palliat Med Care Open Access. 2020;7(1):1-22.

14. Zheng Hui Mah RSMW, Loh REWSEKY, Haidah N, Ahmad Kamal RRSO, Tan LHE, Chiam M, et al. A systematic scoping review of systematic reviews in palliative medicine education. Palliat Med Care Open Access. 2020;7(1):1-12

15. Boden C, Ascher MT, Eldredge JD. Learning while doing: program evaluation of the medical library association systematic review project. J Med Libr Assoc. 2018;106(3):284-93. https://doi.org/10.5195/jmla.2018.286.

16. Hinchcliff R, Greenfield D, Moldovan M, Westbrook Jl, Pawsey M, Mumford $V$, et al. Narrative synthesis of health service accreditation literature. BMJ Qual Saf. 2012;21(12):979-91. https://doi.org/10.1136/bmjqs-2012-000852.

17. Nicholas Mays ER, Popay J. Synthesising research evidence. Studying the organization and delivery of health services: research methods. London: Routledge; 2001. p. 2001.

18. Horsley T. Tips for improving the writing and reporting quality of systematic, scoping, and narrative reviews. J Contin Educ Heal Prof. 2019; 39(1):54-7. https://doi.org/10.1097/CEH.0000000000000241.

19. Munn Z, Peters MDJ, Stern C, Tufanaru C, McArthur A, Aromataris E. Systematic review or scoping review? Guidance for authors when choosing between a systematic or scoping review approach. BMC Med Res Methodol. 2018;18(1):143. https://doi.org/10.1186/s12874-018-0611-x.
20. Tricco AC, Lillie E, Zarin W, O'Brien KK, Colquhoun H, Levac D, et al. PRISMA extension for scoping reviews (PRISMA-SCR): checklist and explanation. Ann Intern Med. 2018;169(7):467-73. https://doi.org/10.7326/M18-0850.

21. Arksey H, O'Malley L. Scoping studies: towards a methodological framework. Int J Soc Res Methodol. 2002;8(1):19-32.

22. Grant MJ, Booth A. A typology of reviews: an analysis of 14 review types and associated methodologies. Health Inf Libr J. 2009;26(2):91-108. https:// doi.org/10.1111/j.1471-1842.2009.00848.x.

23. Lorenzetti DLPS. A scoping review of mentoring programs for academic librarians. J Acad Librariansh. 2015;41(2):186-96. https://doi.org/10.1016/j.aca lib.2014.12.001.

24. Thomas A, Menon A, Boruff J, Rodriguez AM, Ahmed S. Applications of social constructivist learning theories in knowledge translation for healthcare professionals: a scoping review. Implement Sci. 2014;9(1):54. https://doi.org/10.1186/1748-5908-9-54

25. Peters MD, Godfrey CM, Khalil H, Mclnerney P, Parker D, Soares CB. Guidance for conducting systematic scoping reviews. Int J Evid Based Healthc. 2015;13(3):141-6. https://doi.org/10.1097/XEB.0000000000000050.

26. Pham MT, Rajic A, Greig JD, Sargeant JM, Papadopoulos A, McEwen SA. A scoping review of scoping reviews: advancing the approach and enhancing the consistency. Res Synth Methods. 2014;5(4):371-85. https://doi.org/10.1 002/jrsm.1123.

27. Wen Jie Chua CWSC, Lee FQH, Koh EYH, Toh YP, Mason S, Krishna LKR. Structuring mentoring in medicine and surgery. A systematic scoping review of mentoring programs between 2000 and 2019. J Contin Educ Heal Prof. 2020;40(3):158-68.

28. Yong Xiang Ng ZYKK, Yap HW, Tay KT, Tan XH, Ong YT, Tan LHE, et al. Assessing mentoring: a scoping review of mentoring assessment tools in internal medicine between 1990 and 2019. PLoS ONE. 2020;15(5):e0232511.

29. Braun V, Clarke V. Using thematic analysis in psychology. Qual Res Psychol. 2006;3(2):77-101. https://doi.org/10.1191/1478088706qp063oa.

30. Hsieh HF, Shannon SE. Three approaches to qualitative content analysis. Qual Health Res. 2005;15(9):1277-88. https://doi.org/10.1177/1049732305276687.

31. Birden H, Glass N, Wilson I, Harrison M, Usherwood T, Nass D. Defining professionalism in medical education: a systematic review. Med Teach. 2014; 36(1):47-61. https://doi.org/10.3109/0142159X.2014.850154.

32. Goldie J. Assessment of professionalism: a consolidation of current thinking. Med Teach. 2013;35(2):e952-6. https://doi.org/10.3109/0142159X.2012.714888.

33. Hodges B, Paul R, Ginsburg S, The Ottawa Consensus Group M. Assessment of professionalism: from where have we come - to where are we going? An update from the Ottawa Consensus Group on the assessment of professionalism. Med Teach. 2019;41(3):249-55. https://doi.org/10.1080/ 0142159X.2018.1543862.

34. Li H, Ding N, Zhang Y, Liu Y, Wen D. Assessing medical professionalism: a systematic review of instruments and their measurement properties. PLoS One. 2017;12(5):e0177321. https://doi.org/10.1371/journal.pone.0177321.

35. Norcini J, Anderson MB, Bollela V, Burch V, Costa MJ, Duvivier R, et al. 2018 consensus framework for good assessment. Med Teach. 2018;40(11):1102-9. https://doi.org/10.1080/0142159X.2018.1500016.

36. Patterson F, Roberts C, Hanson MD, Hampe W, Eva K, Ponnamperuma G, et al. 2018 Ottawa consensus statement: selection and recruitment to the healthcare professions. Med Teach. 2018;40(11):1091-101. https://doi.org/1 0.1080/0142159X.2018.1498589.

37. Van Der Vleuten CPMSL. Assessing professional competence: from methods to programmes. Med Educ. 2005;39(3):309-17. https://doi.org/10.1111/j.13 65-2929.2005.02094.x.

38. Gordon MGT. STORIES statement: publication standards for healthcare education evidence synthesis. BMC Med. 2014;12(1):143. https://doi.org/1 0.1186/s12916-014-0143-0.

39. Haig A, Dozier M. BEME guide no. 3: systematic searching for evidence in medical education--part 2: constructing searches. Med Teach. 2003;25(5): 463-84. https://doi.org/10.1080/01421590310001608667.

40. Riquelme A, Herrera C, Aranis C, Oporto J, Padilla O. Psychometric analyses and internal consistency of the PHEEM questionnaire to measure the clinical learning environment in the clerkship of a Medical School in Chile. Med Teach. 2009:31(6):e221-5. https://doi.org/10.1080/ 01421590902866226.

41. Schonrock-Adema J, Heijne-Penninga M, Van Hell EA, Cohen-Schotanus J. Necessary steps in factor analysis: enhancing validation studies of educational instruments. The PHEEM applied to clerks as an example. Med Teach. 2009;31(6):e226-32. https://doi.org/10.1080/01421590802516756. 
42. Soemantri D, Herrera C, Riquelme A. Measuring the educational environment in health professions studies: a systematic review. Med Teach. 2010;32(12):947-52. https://doi.org/10.3109/01421591003686229.

43. Sutton $A$. Ethics and law teaching and learning in undergraduate medicine. J Med Ethics. 2010;36(8):511. https://doi.org/10.1136/jme.2010.036350.

44. McKneally MF, Singer PA. Bioethics for clinicians: 25. Teaching bioethics in the clinical setting. CMAJ. 2001;164(8):1163-7.

45. Veloski J, Boex JR, Grasberger MJ, Evans A, Wolfson DB. Systematic review of the literature on assessment, feedback and physicians' clinical performance: BEME Guide No. 7. Med Teach. 2006;28(2):117-28. https://doi.org/10.1080/ 01421590600622665 .

46. Watling CJ, Ginsburg S. Assessment, feedback and the alchemy of learning Med Educ. 2019;53(1):76-85. https://doi.org/10.1111/medu.13645.

47. Sim K, Sum MY, Navedo D. Use of narratives to enhance learning of research ethics in residents and researchers. BMC Med Educ. 2015;15(1):41. https://doi.org/10.1186/s12909-015-0329-y.

48. Stoff BK, Grant-Kels JM, Brodell RT, Paller AS, Perlis CS, Mostow E, et al. Introducing a curriculum in ethics and professionalism for dermatology residencies. J Am Acad Dermatol. 2018;78(5):1032-4. https://doi.org/10.1016/ j.jaad.2017.04.1121.

49. Bercovitch L, Long TP. Dermatoethics: a curriculum in bioethics and professionalism for dermatology residents at Brown Medical School. J Am Acad Dermatol. 2007;56(4):679-82. https://doi.org/10.1016/j.jaad.2006.12.016.

50. Jain S, Dunn LB, Warner CH, Roberts LW. Results of a multisite survey of U.S. psychiatry residents on education in professionalism and ethics. Acad Psychiatry. 2011;35(3):175-83. https://doi.org/10.1176/appi.ap.35.3.175.

51. Vertrees SM, Shuman AG, Fins JJ. Learning by doing: effectively incorporating ethics education into residency training. J Gen Intern Med. 2013:28(4):578-82. https://doi.org/10.1007/s11606-012-2277-0.

52. Bercovitch $L$, Long TP. Ethics education for dermatology residents. Clin Dermatol. 2009;27(4):405-10. https://doi.org/10.1016/j.clindermatol.2009.02.015.

53. Daniel Z, Buchman ELB, lles J. Core strategies for the development of a clinical neuroethics education program for medical residents in the clinical neurosciences. J Ethics Ment Health. 2009:4(2):1-6.

54. Hendee W, Bosma JL, Bresolin LB, Berlin L, Bryan RN, Gunderman RB. Web modules on professionalism and ethics. J Am Coll Radiol. 2012;9(3):170-3. https://doi.org/10.1016/j.jacr.2011.11.014.

55. Lennon-Dearing R, Lowry LW, Ross CW, Dyer AR. An interprofessional course in bioethics: training for real-world dilemmas. J Interprof Care. 2009; 23(6):574-85. https://doi.org/10.3109/13561820902921621.

56. Mehta P, Hester M, Safar AM, Thompson R. Ethics-in-oncology forums. J Cancer Educ. 2007:22(3):159-64. https://doi.org/10.1007/BF03174329.

57. Tolchin B, Willey JZ, Prager K. Education research: a case-based bioethics curriculum for neurology residents. Neurology. 2015;84(13):e91-3. https:// doi.org/10.1212/WNL.0000000000001412.

58. Wada K, Doering $M$, Rudnick $A$. Ethics education for psychiatry residents. A mixed-design retrospective evaluation of an introductory course and a quarterly seminar. Camb Q Healthc Ethics. 2013;22(4):425-35. https://doi. org/10.1017/S0963180113000339.

59. Klingensmith ME. Teaching ethics in surgical training programs using a case-based format. J Surg Educ. 2008;65(2):126-8. https://doi.org/10.1016/j. jsurg.2007.12.001.

60. Carrese JA, McDonald EL, Moon M, Taylor HA, Khaira K, Catherine Beach M, et al. Everyday ethics in internal medicine resident clinic: an opportunity to teach. Med Educ. 2011;45(7):712-21. https://doi.org/10.1111/j.1365-2923.2 011.03931.x

61. Lipworth W, Kerridge I, Little M, Gordon J, Markham P. Meaning and value in medical school curricula. J Eval Clin Pract. 2012;18(5):1027-35. https://doi. org/10.1111/j.1365-2753.2012.01912.x

62. Salih ZN, Boyle DW. Ethics education in neonatal-perinatal medicine in the United States. Semin Perinatol. 2009;33(6):397-404. https://doi.org/10.1053/j. semperi.2009.07.008.

63. Daboval T, Moore GP, Ferretti E. How we teach ethics and communication during a Canadian neonatal perinatal medicine residency: an interactive experience. Med Teach. 2013;35(3):194-200. https://doi.org/10.3109/01421 59X.2012.733452.

64. Liu EY, Batten JN, Merrell SB, Shafer A. The long-term impact of a comprehensive scholarly concentration program in biomedical ethics and medical humanities. BMC Med Educ. 2018;18(1):204. https://doi.org/10.1186/ s12909-018-1311-2.
65. Sherman HB, McGaghie WC, Unti SM, Thomas JX. Teaching pediatrics residents how to obtain informed consent. Acad Med. 2005;80(10 Suppl): S10-3. https://doi.org/10.1097/00001888-200510001-00006.

66. Vora MBSC. Effectiveness of workshop training in basic principles of good clinical practice among the medical teachers - a cross sectional study. Natl J Physiol Pharm Pharmacol. 2011;1(2):92-6.

67. Ramalingam S, Bhuvaneswari S, Sankaran R. Ethics workshops-are they effective in improving the competencies of faculty and postgraduates? J Clin Diagn Res. 2014;8(7):XC01-XC3. https://doi.org/10.7860/JCDR/2014/882 5.4561.

68. Grace AJ, Kirkpatrick HA. Teaching ethics that honor the patient's and the provider's voice: the role of clinical integrity. Int J Psychiatry Med. 2018; 53(5-6):445-54. https://doi.org/10.1177/0091217418791445.

69. Chandra PS, Ragesh G, Chaturvedi SK. Ten-minute snapshots - a team approach to teaching postgraduates about professional dilemmas. Indian J Med Ethics. 2017;2(4):226-30. https://doi.org/10.20529/IJME.2017.052.

70. Howard F, McKneally MF, Levin AV. Integrating bioethics into postgraduate medical education: the University of Toronto model. Acad Med. 2010;85(6): 1035-40. https://doi.org/10.1097/ACM.0b013e3181dbebb8.

71. Cook AFRL. Young physicians' recall about pediatric training in ethics and professionalism and its practical utility. 2013;163(4):1196-201.

72. Cummings $\mathrm{CL}$. Teaching and assessing ethics in the newborn ICU. Semin Perinatol. 2016;40(4):261-9. https://doi.org/10.1053/j.semperi.2015.12.016.

73. Helft PR, Eckles RE, Torbeck $L$. Ethics education in surgical residency programs: a review of the literature. J Surg Educ. 2009;66(1):35-42. https:// doi.org/10.1016/j.jsurg.2008.10.001.

74. Matos FM, Raemer DB. Mixed-realism simulation of adverse event disclosure: an educational methodology and assessment instrument. Simul Healthc. 2013;8(2):84-90. https://doi.org/10.1097/SIH.0b013e31827cbb27.

75. Oljeski SA, Homer MJ, Krackov WS. Incorporating ethics education into the radiology residency curriculum: a model. AJR Am J Roentgenol. 2004;183(3): 569-72. https://doi.org/10.2214/ajr.183.3.1830569.

76. Steinemann S, Furoy D, Yost F, Furumoto N, Lam G, Murayama K. Marriage of professional and technical tasks: a strategy to improve obtaining informed consent. Am J Surg. 2006;191(5):696-700. https://doi.org/10.1016/ j.amjsurg.2006.02.003.

77. Kesselheim JC, Najita J, Morley D, Bair E, Joffe S. Ethics knowledge of recent paediatric residency graduates: the role of residency ethics curricula. J Med Ethics. 2016;42(12):809-14. https://doi.org/10.1136/medethics-2016-103625.

78. Belling C, Coulehan J. A window of opportunity: ethics and professionalism in the obstetrics and gynecology clerkship. Teach Learn Med. 2006;18(4): 326-9. https://doi.org/10.1207/s15328015tlm1804_9.

79. Byrne J, Straub H, DiGiovanni L, Chor J. Evaluation of ethics education in obstetrics and gynecology residency programs. Am J Obstet Gynecol. 2015; 212(3):397 e1-8.

80. Ghias K, Ahmer S. Guarding the guardians: bioethics curricula for psychiatrists-in-training in developing countries. Int Rev Psychiatry. 2010; 22(3):294-300. https://doi.org/10.3109/09540261.2010.482096.

81. Grossman $\mathrm{E}_{1}$ Posner MC, Angelos P. Ethics education in surgical residency: past, present, and future. Surgery. 2010;147(1):114-9. https://doi.org/10.101 6/j.surg.2009.04.011.

82. Bennett KG, Ingraham JM, Schneider LF, Saadeh PB, Vercler CJ. The teaching of ethics and professionalism in plastic surgery residency: a cross-sectional survey. Ann Plast Surg. 2017;78(5):552-6. https://doi.org/10.1097/SAP. 0000000000000919.

83. Tsao Cl, Guedet PJ. Ethics and professionalism preparation for psychiatristsin-training: a curricular proposal. Int Rev Psychiatry. 2010;22(3):301-5. https:// doi.org/10.3109/09540261.2010.482095.

84. Howard F, McKneally MF, Upshur RE, Levin AV. The formal and informal surgical ethics curriculum: views of resident and staff surgeons in Toronto. Am J Surg. 2012;203(2):258-65. https://doi.org/10.1016/j.amjsurg.2011.02.008.

85. Robb A, Etchells E, Cusimano MD, Cohen R, Singer PA, McKneally M. A randomized trial of teaching bioethics to surgical residents. Am J Surg. 2005;189(4):453-7. https://doi.org/10.1016/j.amjsurg.2004.08.066.

86. Cheung L. Creating an ethics curriculum using a structured framework. Int J Med Educ. 2017:8:142-3. https://doi.org/10.5116/ijme.58ed.e607.

87. Huijer M, van Leeuwen E, Boenink A, Kimsma G. Medical students' cases as an empirical basis for teaching clinical ethics. Acad Med. 2000;75(8):834-9. https://doi.org/10.1097/00001888-200008000-00017.

88. Steinemann D, Skawran B, Becker T, Tauscher M, Weigmann A, Wingen L, et al. Assessment of differentiation and progression of hepatic tumors using 
array-based comparative genomic hybridization. Clin Gastroenterol Hepatol. 2006;4(10):1283-91. https://doi.org/10.1016/j.cgh.2006.07.010.

89. Walsh BC, Karia R, Egol K, Zuckerman JD, Phillips D. Teaching professionalism in orthopaedic residency: efficacy of the American academy of orthopaedic surgeons ethics modules. J Am Acad Orthop Surg. 2018; 26(14):507-14. https://doi.org/10.5435/JAAOS-D-16-00386.

90. Goold SD, Stern DT. Ethics and professionalism: what does a resident need to learn? Am J Bioeth. 2006;6(4):9-17. https://doi.org/10.1080/152651 60600755409.

91. Gupta M, Forlini C, Lenton K, Duchen R, Lohfeld L. The hidden ethics curriculum in two Canadian psychiatry residency programs: a qualitative study. Acad Psychiatry. 2016;40(4):592-9. https://doi.org/10.1007/s40596-0150456-0.

92. Kon AA. Resident-generated versus instructor-generated cases in ethics and professionalism training. Philos Ethics Humanit Med. 2006;1(1):E10.

93. Taylor HA, McDonald EL, Moon M, Hughes MT, Carrese JA. Teaching ethics to paediatrics residents: the centrality of the therapeutic alliance. Med Educ. 2009;43(10):952-9. https://doi.org/10.1111/j.1365-2923.2009.03449.x.

94. McClean KL, Card SE. Informed consent skills in internal medicine residency: how are residents taught, and what do they learn? Acad Med. 2004;79(2): 128-33. https://doi.org/10.1097/00001888-200402000-00006.

95. Brajenovic-Milic B, Ristic S, Kern J, Vuletic S, Ostojic S, Kapovic M. The effect of a compulsory curriculum on ethical attitudes of medical students. Coll Antropol. 2000;24(1):47-52.

96. Carrese JA, Malek J, Watson K, Lehmann LS, Green MJ, McCullough LB, et al. The essential role of medical ethics education in achieving professionalism: the Romanell report. Acad Med. 2015;90(6):744-52. https://doi.org/10.1097/A CM.0000000000000715.

97. Lang CW, Smith PJ, Ross LF. Ethics and professionalism in the pediatric curriculum: a survey of pediatric program directors. Pediatrics. 2009;124(4): 1143-51. https://doi.org/10.1542/peds.2009-0658.

98. Moreno Villares JMGCE. An ethics curriculum for the pediatric residency program: experience of a university hospital. An Pediatr. 2003;58(4):333-8. https://doi.org/10.1016/S1695-4033(03)78067-9.

99. Goodrich TJIC, Boccher-Lattimore D. Narrative ethics as collaboration: a foursession curriculum. Fam Syst Health. 2005;23(3):348-57. https://doi.org/10.1 037/1091-7527.23.3.348.

100. Beresin EV, Baldessarini RJ, Alpert J, Rosenbaum J. Teaching ethics of psychopharmacology research in psychiatric residency training programs. Psychopharmacology. 2003;171(1):105-11. https://doi.org/10.1007/s00213003-1434-x.

101. Benbassat J, Baumal R. What is empathy, and how can it be promoted during clinical clerkships? Acad Med. 2004;79(9):832-9. https://doi.org/10.1 097/00001888-200409000-00004.

102. Buchman DZ, Russell BJ. Addictions, autonomy and so much more: a reply to Caplan. Addiction. 2009;104(6):1053-4 author reply 4-5.

103. Al-Mahroos F, Bandaranayake RC. Teaching medical ethics in medical schools. Ann Saudi Med. 2003;23(1-2):1-5. https://doi.org/10.5144/0256-494 7.2003.1.

104. Bentwich ME, Bokek-Cohen Y. Process factors facilitating and inhibiting medical ethics teaching in small groups. J Med Ethics. 2017;43(11):771-7. https://doi.org/10.1136/medethics-2016-103947.

105. Kanter SL, Wimmers PF, Levine AS. In-depth learning: one school's initiatives to foster integration of ethics, values, and the human dimensions of medicine. Acad Med. 2007;82(4):405-9. https://doi.org/10.1097/ACM.0b013 e318033373c.

106. Kong WM, Knight S. Bridging the education-action gap: a near-peer casebased undergraduate ethics teaching programme. J Med Ethics. 2017;43(10): 692-6. https://doi.org/10.1136/medethics-2016-103762.

107. Robeson R, King NMP. Performable case studies in ethics education. Healthcare (Basel). 2017;5(3).

108. Lewin LO, Lanken PN. Longitudinal small-group learning during the first clinical year. Fam Med. 2004;36(Suppl):S83-8

109. Tsai TC, Harasym PH. A medical ethical reasoning model and its contributions to medical education. Med Educ. 2010;44(9):864-73. https:// doi.org/10.1111/j.1365-2923.2010.03722.x.

110. Wasson K, Bading E, Hardt J, Hatchett L, Kuczewski MG, McCarthy M, et al. Physician, know thyself: the role of reflection in bioethics and professionalism education. Narrat Inq Bioeth. 2015;5(1):77-86. https://doi. org/10.1353/nib.2015.0019.
111. Hafferty FW, Franks R. The hidden curriculum, ethics teaching, and the structure of medical education. Acad Med. 1994;69(11):861-71. https://doi. org/10.1097/00001888-199411000-00001.

112. Patrinely JR Jr, Drolet BC, Perdikis G, Janis J. Ethics education in plastic surgery training programs. Plast Reconstr Surg. 2019;144(3):532e-3e.

113. Andre J, Brody H, Fleck L, Thomason C, Tomlinson T. Ethics, professionalism, and humanities at Michigan State University College of Human Medicine. Acad Med. 2003;78(10):968-72. https://doi.org/10.1097/00001888-20031 0000-00005

114. Lehmann LS, Kasoff WS, Koch P, Federman DD. A survey of medical ethics education at U.S. and Canadian medical schools. Acad Med. 2004;79(7):6829. https://doi.org/10.1097/00001888-200407000-00015.

115. Cohn JM. Bioethics curriculum for paediatrics residents: implementation and evaluation. Med Educ. 2005;39(5):530. https://doi.org/10.1111/j.1365-2929.2 005.02152.x

116. Lohfeld L, Goldie J, Schwartz L, Eva K, Cotton P, Morrison J, et al. Testing the validity of a scenario-based questionnaire to assess the ethical sensitivity of undergraduate medical students. Med Teach. 2012;34(8):635-42. https://doi. org/10.3109/0142159X.2012.687845.

117. Malek J, Geller G, Sugarman J. Talking about cases in bioethics: the effect of an intensive course on health care professionals. J Med Ethics. 2000;26(2): 131-6. https://doi.org/10.1136/jme.26.2.131.

118. Tsai TC, Harasym PH, Coderre S, McLaughlin K, Donnon T. Assessing ethical problem solving by reasoning rather than decision making. Med Educ. 2009;43(12):1188-97. https://doi.org/10.1111/j.1365-2923.2009.03516.x.

119. Viswanath B, Jayarajan RN, Chandra PS, Chaturvedi SK. Supplementing research ethics training in psychiatry residents: a five-tier approach. Asian J Psychiatr. 2018;34:54-6. https://doi.org/10.1016/j.ajp.2018.04.003.

120. Fanous A, Rappaport J, Young M, Park YS, Manoukian J, Nguyen LHP. A longitudinal simulation-based ethical-legal curriculum for otolaryngology residents. Laryngoscope. 2017;127(11):2501-9. https://doi.org/10.1002/lary.26551.

121. Moon MR, Hughes MT, Chen JY, Khaira K, Lipsett P, Carrese JA. Ethics skills laboratory experience for surgery interns. J Surg Educ. 2014;71(6):829-38. https://doi.org/10.1016/j.jsurg.2014.03.010.

122. Moore GP, Ferretti E, Daboval T. Developing a knowledge test for a neonatal ethics teaching program. Cureus. 2017;9(12):e1971. https://doi. org/10.7759/cureus.1971.

123. Strong C, Beckmann CR, Dacus JV. A conference on ethics for obstetric and gynaecological clerkship students. Med Educ. 1992;26(5):354-9. https://doi. org/10.1111/j.1365-2923.1992.tb00185.x.

124. Sulmasy DP, Geller G, Levine DM, Faden RR. A randomized trial of ethics education for medical house officers. J Med Ethics. 1993;19(3):157-63. https://doi.org/10.1136/jme.19.3.157.

125. Kotzee B, Ignatowicz A. Measuring 'virtue' in medicine. Med Health Care Philos. 2016;19(2):149-61. https://doi.org/10.1007/s11019-015-9653-6.

126. Pauls MA. Teaching and evaluation of ethics and professionalism: in Canadian family medicine residency programs. Can Fam Physician. 2012; 58(12):e751-6.

127. Cook AF, Sobotka SA, Ross LF. Teaching and assessment of ethics and professionalism: a survey of pediatric program directors. Acad Pediatr. 2013; 13(6):570-6. https://doi.org/10.1016/j.acap.2013.07.009.

128. Dingle AD, Kolli V. Ethics in child and adolescent psychiatry training: what and how are we teaching? Acad Psychiatry. 2020;44(2):168-78. https://doi. org/10.1007/s40596-019-01149-0.

129. Mohamed AM, Ghanem MA, Kassem A. Knowledge, perceptions and practices towards medical ethics among physician residents of University of Alexandria Hospitals, Egypt. East Mediterr Health J. 2012;18(9):935-45. https://doi.org/10.26719/2012.18.9.935.

130. Pascual-Ramos V, Contreras-Yanez I, Arce Salinas CA, Saavedra Salinas MA, Del Mercado M, Lopez Zepeda J, et al. Evaluation of medical ethics competencies in rheumatology: local experience during national accreditation process. J Med Ethics. 2019;45(12):839-42. https://doi.org/1 0.1136/medethics-2019-105717.

131. Cruess RL, Cruess SR, Steinert Y. Amending Miller's pyramid to include professional identity formation. Acad Med. 2016;91(2):180-5. https://doi. org/10.1097/ACM.0000000000000913.

132. Norcini J. Is it time for a new model of education in the health professions? Med Educ. 2020;54(8):687-90. https://doi.org/10.1111/medu.14036.

133. Ten Cate O, Taylor DR. The recommended description of an entrustable professional activity: AMEE Guide No. 140. Med Teach. 2020:1-9. 
134. Cruess RL, Cruess SR, Boudreau JD, Snell L, Steinert Y. Reframing medical education to support professional identity formation. Acad Med. 2014; 89(11):1446-51. https://doi.org/10.1097/ACM.0000000000000427.

135. de la Garza S, Phuoc V, Throneberry S, Blumenthal-Barby J, McCullough L, Coverdale J. Teaching medical ethics in graduate and undergraduate medical education: a systematic review of effectiveness. Acad Psychiatry. 2017;41(4):520-5. https://doi.org/10.1007/s40596-016-0608-x.

136. Challis M. AMEE Medical Education Guide No. 11 (revised): portfolio-based learning and assessment in medical education. Med Teach. 1999;21(4):37086.

137. Mathers NJ, Challis MC, Howe AC, Field NJ. Portfolios in continuing medical education--effective and efficient? Med Educ. 1999;33(7):521-30. https://doi. org/10.1046/j.1365-2923.1999.00407.x.

138. Dawe R, Pike A, Kidd M, Janakiram P, Nicolle E, Allison J. Enhanced skills in global health and health equity: guidelines for curriculum development. Can Med Educ J. 2017;8(2):e48-60. https://doi.org/10.36834/cmej.36885.

139. Fins JJ, Kodish E, Cohn F, Danis M, Derse AR, Dubler NN, et al. A pilot evaluation of portfolios for quality attestation of clinical ethics consultants. Am J Bioeth. 2016;16(3):15-24. https://doi.org/10.1080/15265161.2015.1134 705.

140. Robert M, Jarvis PSOS, McClain T, Clardy JA. Can one portfolio measure the six ACGME general competencies? Acad Psychiatry. 2004;28(3):190-6.

141. Jenkins L, Mash B, Derese A. Development of a portfolio of learning for postgraduate family medicine training in South Africa: a Delphi study. BMC Fam Pract. 2012;13(1):11. https://doi.org/10.1186/1471-2296-13-11.

142. O'Sullivan P, Greene C. Portfolios: possibilities for addressing emergency medicine resident competencies. Acad Emerg Med. 2002;9(11):1305-9. https://doi.org/10.1197/aemj.9.11.1305.

143. Watling CJ, Brown JB. Education research: communication skills for neurology residents: structured teaching and reflective practice. Neurology. 2007;69(22):E20-6. https://doi.org/10.1212/01.wnl.0000280461.96059.44

144. Cruess RL, Cruess SR, Steinert Y. Medicine as a community of practice: implications for medical education. Acad Med. 2018;93(2):185-91. https:// doi.org/10.1097/ACM.0000000000001826.

145. Silverman HJ. Organizational ethics in healthcare organizations: proactively managing the ethical climate to ensure organizational integrity. HEC Forum. 2000:12(3):202-15. https://doi.org/10.1023/A:1008985411047.

146. Jarvis-Selinger S, Pratt DD, Regehr G. Competency is not enough: integrating identity formation into the medical education discourse. Acad Med. 2012;87(9):1185-90. https://doi.org/10.1097/ACM.0b013e3182604968.

147. Levac D, Colquhoun H, O'Brien KK. Scoping studies: advancing the methodology. Implement Sci. 2010;5(1):69. https://doi.org/10.1186/17485908-5-69.

148. Charles C, Gafni A, Whelan T. Shared decision-making in the medical encounter: what does it mean? (or it takes at least two to tango). Soc Sci Med. 1997;44(5):681-92. https://doi.org/10.1016/S0277-9536(96)00221-3.

149. Frank JR, MMEF. The CanMEDS 2005 physician competency framework. Better standards. Better physicians. Better care: Royal College of Physicians and Surgeons of Canada; 2005.

\section{Publisher's Note}

Springer Nature remains neutral with regard to jurisdictional claims in published maps and institutional affiliations.

Ready to submit your research? Choose BMC and benefit from:

- fast, convenient online submission

- thorough peer review by experienced researchers in your field

- rapid publication on acceptance

- support for research data, including large and complex data types

- gold Open Access which fosters wider collaboration and increased citations

- maximum visibility for your research: over $100 \mathrm{M}$ website views per year

At $\mathrm{BMC}$, research is always in progress.

Learn more biomedcentral.com/submissions 